\title{
ВПЛИВ ТЕХНОЛОГІЧНОГО ВДОСКОНАЛЕННЯ СПОСОБІВ ЗАБЕЗПЕЧЕННЯ ПОВНОЦІННИМ ЖИВЛЕННЯМ ПОРОСЯТ НА БІОХІМІЧНІ ПОКАЗНИКИ КРОВІ
}

\author{
Косов Микола Олександрович \\ молодший науковий співробітник \\ Інститут тваринництва НААН \\ ORCID: 0000-0002-8850-745X \\ Email:nkosov479@gmail.com \\ Капітонова Олена Алевтинівна \\ кандидат сільськогосподарських наук, доцент \\ 30 «Вітебська ордена «Знак Пошани» державна \\ академія ветеринарної медицини», м. Вітебськ, Білорусь \\ ORCID: 0000-0003-4307-8433 \\ Email: kapitonovalena1110@mail.ru
}

\begin{abstract}
Висвітлено результати впливу розроблених балансуючих кормових добавок в складі малокомпонентних комбікормів виготовлених на розробленому агрегаті на морфрологічний і біохімічний склад крові поросят. Вивчення ефрективності використання балансуючих добавок в складі малокомпонентних комбікормів виготовлених на розробленому агрегаті, було проведено в експериментальних дослідженнях по визначенню продуктивної дії їх на головні господарсько-корисні ознаки поросят на дорощуванні. Рецептура розроблених балансуючих добавок і комбікорму на основі зернової частини з пшениці і ячменю проводилася в виробничих умовах на поросятах породи уельс (2-4 місяиі) живою масою від 20 кә до 40 ке на збалансованих раціонах за всіма поживними речовинами: білком, вуглеводами, жирами, мінеральними речовинами, вітамінами, ферментами та іншими. Дослідні групи поросят відрізнялися зерновою частиною комбікорму і розробленим складом БВМД для кожної групи окремо: I дослідна група - ячмінь + БВМД №1, II дослідна - ячмінь + пшениця + БВМД №2, III дослідна - пшениия + БВМД №3, IV контрольна - на господарському раціоні на основі дерті ячмінної. Результати вивчення білка і білкових фрракцій крові свідчать, що зміна рівня загального білка в крові спостерігається в усіх групах тільки з віком і відповідає фізіологічній нормі, без істотної різниці між дослідними і контрольними тваринами. У 2-х місячному віці вміст загального білка в сироватиі крові був на рівні від 6,21 г\% до 6,69 г\% при невірогідный різниці між групами. У порівнянні з ним, в 4-х місячному віці, він збільшився з 6,34 г\% до 7,25 г\%. Спостерігалася тенденція збільшення вмісту альбуміну, алфа-, бета- і гамма-глобулінів з віком у всіх групах. Результати вивчення лізоцимної активності показали зменшення їі з віком в I i II групах в 0,88 рази і 0,93 рази і збільшення в III i IV групах в 1,04 i 1,28 рази. Вірогідна різниця лізоцимної активності була в 2 місяці I $\mathrm{i}$ III груп при P> 0,90 у порівнянні з контролем. Отримані дані за морфоологічним $i$ біохімічним складом крові поросят при вирощуванні за показниками вмісту гемоглобіну та еритроцитів показали, що більш високопродуктивна група тварин мала тенденцію до збільшення. Вікові зміни інших показників відповідали фізіологічного стану і не виходили за межі фізіологічних норм. показники білкових фракцій і опсоно-фрагоцитарні реакції.
\end{abstract}

Ключові слова: поросята, кров, опсоно-фрагоцитарна реакція, гемоглобін, лейкоцити, кормова добавка, концкорми, рецеnтура, раціон.

DOl: https://doi.org/10.32845/bsnau.lvst.2020.4.7

Виробництво високоякісних комбікормів одна з основних задач в справі підвищення продуктивності тварин і зниження витрат кормів на одиницю продукції. Високий генетичний потенціал сучасних порід і кросів тварин, висока інтенсивність фізіологічних і біохімічних процесів вимагають постійного і стабільного надходження в організм поживних і біологічно активних речовин.

Царенко О.М., Крятова Р.Є., Бондарчук Л.В. (2004) вважають, підвищення ефективності галузі тваринництва в значній мірі обумовлено вдосконаленням існуючих та розробкою нових технологій виробництва продукції. Такої думки дотримуються багато авторів, зокрема, Демчук О.В. та ін., (2004), Зайцев В., Майстренко А. (2016), Церенюк О. М., та iн., (2020), Tsereniuk, O. M., et all., (2020), та інші. Серед них велике значення надається технологічним прийомам виробництва кормових повнораціонних сумішей збалансованих за основними поживними речовинами, які відповідають фізіологічним потребам тварин і забезпечують високу реалізацію генетичного потенціалу їх продуктивності.

Залежно від стану кормової бази в господарстві в бі-

льшості відгодовують свиней концкормами або сумішшю різних кормів (концкормів, соковиті і грубі корми, харчові відходи і т.д.). Для швидкого нарощування виробництва м'яса і при відсутності концкормів в більшості господарств доцільно використовувати корми власного виробництва, Зайцев В., Майстренко А., 2016, Демчук О.В. і ін., 2004 і інші. При виготовленні комбікормів і кормових сумішей в агросірмах різної власності використовують різні механізми. Вони, як правило, великогабаритні і дорогі. Принцип їх роботи заснований на поточності подачі інгредієнтів на стрічковий транспортер з дозаторів. Головний недолік таких цехів (механізмів) полягає в тому, що вони не забезпечують гомогенності готового продукту при змішуванні, що значно знижує ефективність їх використання. Наукові дослідження і практика за останні десятиліття свідчать про доцільність використання в годівлі тварин малокомпонентних комбікормів, Рижов С. (2000). При цьому, як підтверджує практика, такі комбікорми доцільно виробляти безпосередньо в кормоцехах господарств. Запропонована ним технікотехнологічна схема приготування комбікормів безпосеред- 
ньо в агрофрормуваннях забезпечує однорідність продукції на рівні $98 \%$, що сприяє підвищенню ефективності годівлі тварин і птиці. Встановлено, що одна тонна комбікормової продукції, виготовлена в господарстві на авторській установці, дешевше і ефективніше, ніж стандартні комбікорми і кормові добавки вітчизняного та імпортного виробництва.

Однією з умов отримання високоякісної продукції і економного використання кормів $€$ застосування балансуючих добавок, які містять необхідні енергетичні і біологічно активні речовини, усуваючи їх десріцит в кормах і виконуючи роль каталізаторів (прискорювачів) обмінних процесів в організмі.

Кровотворна система завжди характеризує зміни, що відбуваються в організмі і клінічний аналіз крові може відображати ці зміни. Вивчення фізіологічного стану та інтенсивності обміну речовин у тварин в більшій мірі характеризується морфологічним та біохімічним складом крові, а на інтенсивність обмінних і окислювально-відновних процесів в організмі впливають як генотипи так і паратипові фактори [5].

Вченими доведено, що біохімічний склад крові може служити показником функціонального стану організму і бути використаним для прогнозування продуктивності тварин і якості м'яса [9].

Від морфологічного і біохімічного складу крові в значній мірі залежить інтенсивність обмінних і окислювальновідновних процесів в організмі свиней, і за якими можна стверджувати про інтенсивність обміну речовин, які в свою чергу впливають на рівень продуктивності.

Метою роботи стало вивчення впливу на організм поросят розроблених балансуючих кормових добавок в складі малокомпонентних комбікормів, виготовлених на розробленому агрегаті, на морфологічний і біохімічний склад крові.

Матеріали та методи досліджень. Вивчення ефективності використання балансуючих добавок в складі малокомпонентних комбікормів виготовлених на розробленому агрегаті, було проведено в експериментальних дослідженнях по визначенню продуктивної дії їх на головні господарсько-корисні ознаки поросят на дорощуванні.

Рецептура розроблених балансуючих добавок і комбікорму на основі зернової частини з пшениці і ячменю проводилася в виробничих умовах на поросятах породи Уельс
(2-4 місяці) живою масою від 20 кг до 40 кг на збалансованих раціонах за всіма поживними речовинами: білком, вуглеводами, жирами, мінеральними речовинами, вітамінами, ферментами та іншими.

Дослідні групи поросят відрізнялися зерновою частиною комбікорму і розробленим складом БВМД для кожної групи окремо: І дослідна група - ячмінь + БВМД №1, II дослідна - ячмінь + пшениця + БВМД №2, III дослідна - пшениця + БВМД №3, IV контрольна - на господарському раціоні на основі дерті ячмінної. Порівняння всіх показників продуктивності поросят на дорощуванні проводили між дослідними групами і контролем.

Фізіологічний стан поросят оцінювали за гематологічними показниками крові, в якій встановлювали показники білкових фракцій і опсоно-фрагоцитарні реакції.

Параметри опсоно-фагоцитарної реакції оцінювали за фагоцитарної активності (частка нейтрофілів, яка брала участь в фагоцитозі по відношенню до загальної кількості нейтрофілів), фагоцитарного індексу (за кількістю мікроорганізмів, фагоцитованих 1 активним нейтрофілом), фагоцитарного числа (за кількістю мікроорганізмів, фрагоцитованих 1 середньостатистичним нейтрофілом) і фагоцитарної ємністю (за кількістю мікроорганізмів фагоцитованих нейтрофілами одного літра крові). Лізоцимну активність, визначали ферментативним шляхом і відображали в мкг/мл. Дослідження проводилися в лабораторії зоохімічного аналізу Інституту тваринництва НААН за загальноприйнятими методиками $[6,7]$.

Результати досліджень. Відомо, що склад крові відрізняється відносною сталістю, що забезпечує збереження видових індивідуальних особливостей конституції тварин. Але поряд 3 цим, склад крові досить варіабельний, що дозволяє використовувати його в якості механізму, що може судити про ступінь адаптації того чи іншого організму в умовах зовнішнього середовища, Э.В. Эйдригевича, В.В. Раевской (1978).

Морфологічні показники крові поросят відповідних груп з різним рівнем зернової частини в складі комбікорму свідчать, що при постановці на вирощування у віці 2-х місяців за кількістю еритроцитів і гемоглобіну ймовірної переваги між групами не виявлено, що свідчить про добру вирівняність цих тварин на початок досліду, таблиця 1.

Таблиця 1

Гематологічні показники крові поросят на початок і кінець досліду

\begin{tabular}{|c|c|c|c|c|c|c|c|c|}
\hline \multirow{3}{*}{ Показники } & \multicolumn{8}{|c|}{ Періоди росту, місяці } \\
\hline & \multicolumn{2}{|c|}{ I група } & \multicolumn{2}{|c|}{ II група } & \multicolumn{2}{|c|}{ III група } & \multicolumn{2}{|c|}{ IV група } \\
\hline & 2 міс. & 4 міс. & 2 міс. & 4 міс. & 2 міс. & 4 міс. & 2 міс. & 4 міс. \\
\hline Концентрація гемоглобіну, г/\%, & $12,66 \pm 0,14$ & $11,96 \pm 0,41$ & $12,12 \pm 0,30$ & $11,76 \pm 0,39$ & $12,10 \pm 0,41$ & $11,46 \pm 0,37$ & $11,86 \pm 0,29$ & $11,94 \pm 0,25$ \\
\hline Кількість ери-троцитів, 1012/л, & $5,26 \pm 0,07$ & $5,02 \pm 0,16$ & $5,16 \pm 0,10$ & $4,95 \pm 0,18$ & $4,98 \pm 0,12$ & $4,87 \pm 0,17$ & $5,00 \pm 0,12$ & $4,92 \pm 0,16$ \\
\hline Кількість лейкоцитів, 10 /л, & $30,10 \pm 1,17$ & $11,17 \pm 0,57$ & $27,58 \pm 1,80$ & $12,42 \pm 0,71$ & $27,00 \pm 1,96$ & $13,62 \pm 1,10$ & $30,61 \pm 0,89$ & $15,56 \pm 2,34$ \\
\hline \multicolumn{9}{|l|}{ Лейкоцитарна формула, \%: } \\
\hline базофіли & $1,40 \pm 0,77$ & $1,60 \pm 0,57$ & $1,80 \pm 0,20$ & $4,40 \pm 1,44$ & $1,00 \pm 0,58$ & $4,00 \pm 1,00$ & $1,80 \pm 0,37$ & $3,20 \pm 0,58$ \\
\hline еозинофіли & $11,80 \pm 1,53$ & $3,00 \pm 0,55$ & $14,20 \pm 0,86$ & $2,80 \pm 0,96$ & $11,00 \pm 2,65$ & $5,60 \pm 0,24$ & $7,80 \pm 1,91$ & $4,00 \pm 1,10$ \\
\hline лімфоцити & $52,40 \pm 1,21$ & $57,40 \pm 2,79$ & $48,60 \pm 3,03$ & $66,40 \pm 2,98$ & $58,80 \pm 3,12$ & $57,40 \pm 4,41$ & $58,80 \pm 4,26$ & $57,40 \pm 3,26$ \\
\hline моноцити & $2,80 \pm 1,19$ & $4,20 \pm 1,67$ & $2,60 \pm 0,60$ & $3,60 \pm 0,51$ & $2,80 \pm 1,14$ & $2,60 \pm 1,35$ & $1,80 \pm 0,20$ & $3,80 \pm 0,66$ \\
\hline паличкоядерні & $0,80 \pm 0,48$ & $1,20 \pm 0,75$ & $1,00 \pm 0,71$ & $0,80 \pm 0,48$ & $0,00 \pm 0,00$ & $2,40 \pm 0,68$ & $0,40 \pm 0,39$ & $0,60 \pm 0,63$ \\
\hline сегментоядерні & $30,60 \pm 1,21$ & $57,40 \pm 2,79$ & $31,40 \pm 3,08$ & $66,40 \pm 2,98$ & $26,40 \pm 2,58$ & $57,40 \pm 4,41$ & $29,40 \pm 2,56$ & $57,40 \pm 3,26$ \\
\hline
\end{tabular}

На кінець досліду спостерігалися незначні зміни цих показників у порівнянні з попереднім віком і в розрізі окремих груп.
Коливання кількості гемоглобіну також обумовлені віком тварин, умовою годівлі, що підтверджується і нашими дослідженнями. 
Кількість лейкоцитів з віком зменшилася майже вдвічі і в межах кожної групи цей показник не мав істотних відмінностей.

Вікові зміни лейкоцитарної формули відповідали фрізіологічному стану поросят в період їх вивчення і не виходили за межі фрізіологічних норм.

Динаміка білка і білкових фрракцій крові наведені в таблиці 2. Результати вивчення цих показників свідчать, що зміна рівня загального білка в крові спостерігається в усіх групах тільки з віком і відповідає фізіологічній нормі, без істотної різниці між дослідними і контрольними тваринами. У 2-х місячному віці вміст загального білка в сироватці крові був на рівні від 6,21 г\% до 6,69 г\% при невірогідный різниці між групами. У порівнянні з ним, в 4-х місячному віці, він збільшився з 6,34 г\% до 7,25 г\%. Спостерігалася тенденція збільшення вмісту альбуміну, алфа-, бета- і гаммаглобулінів з віком у всіх групах.

Таблиця 2

Показники рівня білка і білкових фракцій крові поросят на початок і кінець досліду

\begin{tabular}{|c|c|c|c|c|c|c|c|c|}
\hline \multirow{3}{*}{ Показники } & \multicolumn{8}{|c|}{ Періоди росту, місяці } \\
\hline & \multicolumn{2}{|c|}{ I група } & \multicolumn{2}{|c|}{ |I група } & \multicolumn{2}{|c|}{ III група } & \multicolumn{2}{|c|}{ IV група } \\
\hline & 2 мес. & 4 мес. & 2 мес. & 4 мес. & 2 мес. & 4 мес. & 2 мес. & 4 мес. \\
\hline Загальний білок, г/\% & $\begin{array}{c}6,69 \pm \\
0,10\end{array}$ & $\begin{array}{c}7,14 \pm \\
0,22\end{array}$ & $\begin{array}{c}6,52 \pm \\
0,17\end{array}$ & $\begin{array}{c}7,23 \pm \\
0,34\end{array}$ & $\begin{array}{c}6,21 \pm \\
0,27\end{array}$ & $\begin{array}{c}6,34 \pm \\
0,28\end{array}$ & $\begin{array}{c}6,25 \pm \\
0,24\end{array}$ & $\begin{array}{c}7,25 \pm \\
0,35\end{array}$ \\
\hline Альбумін, г/\% & $\begin{array}{c}2,13 \pm \\
0,06\end{array}$ & $\begin{array}{c}2,47 \pm \\
0,13\end{array}$ & $\begin{array}{c}2,05 \pm \\
0.07\end{array}$ & $\begin{array}{c}2,38 \pm \\
0,15\end{array}$ & $\begin{array}{c}1,94 \pm \\
0,05\end{array}$ & $\begin{array}{c}1,96 \pm \\
0,07\end{array}$ & $\begin{array}{c}1,81 \pm \\
0,08\end{array}$ & $\begin{array}{c}1,93 \pm \\
0,06\end{array}$ \\
\hline Глобуліни, г/\%: & $\begin{array}{c}4,56 \pm \\
0,11\end{array}$ & $\begin{array}{c}4,65 \pm \\
0,10\end{array}$ & $\begin{array}{c}4,47 \pm \\
0,12\end{array}$ & $\begin{array}{c}4,85 \pm \\
0,20\end{array}$ & $\begin{array}{c}4,26 \pm \\
0,24\end{array}$ & $\begin{array}{c}4,38 \pm \\
0,22\end{array}$ & $\begin{array}{c}4,42 \pm \\
0,18\end{array}$ & $\begin{array}{c}4,06 \pm \\
0,31\end{array}$ \\
\hline Альфа-глобуліни, г/\% & $\begin{array}{c}1,65 \pm \\
0,06\end{array}$ & $\begin{array}{c}2,12 \pm \\
0,06\end{array}$ & $\begin{array}{c}1,63 \pm \\
0,10\end{array}$ & $\begin{array}{c}2,08 \pm \\
0,10\end{array}$ & $\begin{array}{c}1,50 \pm \\
0,09\end{array}$ & $\begin{array}{c}1,72 \pm \\
0,12\end{array}$ & $\begin{array}{c}1,56 \pm \\
0,10\end{array}$ & $\begin{array}{c}2,15 \pm \\
0,08\end{array}$ \\
\hline Бета-глобуліни, г/\% & $\begin{array}{c}1,21 \pm \\
0,08\end{array}$ & $\begin{array}{c}0,76 \pm \\
0,06\end{array}$ & $\begin{array}{c}1,06 \pm \\
0,10\end{array}$ & $\begin{array}{c}0,89 \pm \\
0,06\end{array}$ & $\begin{array}{c}1,01 \pm \\
0,08\end{array}$ & $\begin{array}{c}0,87 \pm \\
0,05\end{array}$ & $\begin{array}{c}0,96 \pm \\
0,09\end{array}$ & $\begin{array}{c}1,06 \pm \\
0,07\end{array}$ \\
\hline Гамма-глобуліни, г/\% & $\begin{array}{c}1,70 \pm \\
0,12\end{array}$ & $\begin{array}{c}1,78 \pm \\
0,06\end{array}$ & $\begin{array}{c}1,78 \pm \\
0,04\end{array}$ & $\begin{array}{c}1,88 \pm \\
0,09\end{array}$ & $\begin{array}{c}1,74 \pm \\
0,17\end{array}$ & $\begin{array}{c}1,80 \pm \\
0,15\end{array}$ & $\begin{array}{c}1,91 \pm \\
0,04\end{array}$ & $\begin{array}{c}2,06 \pm \\
0,18\end{array}$ \\
\hline Коефіциєнт А/Г & $\begin{array}{c}0,47 \pm \\
0,02\end{array}$ & $\begin{array}{c}0,53 \pm \\
0,02\end{array}$ & $\begin{array}{c}0,46 \pm \\
0,01\end{array}$ & $\begin{array}{c}0,49 \pm \\
0,02\end{array}$ & $\begin{array}{c}0,46 \pm \\
0,02\end{array}$ & $\begin{array}{c}0,48 \pm \\
0,02\end{array}$ & $\begin{array}{c}0,41 \pm \\
0,02\end{array}$ & $\begin{array}{c}0,38 \pm \\
0,02\end{array}$ \\
\hline
\end{tabular}

Вищий рівень альбуміну в 2-х місячному віці був у поросят I i II дослідних груп з переважанням від контролю на $17,67 \%$, P> 0,95 і 13,25 \%, P> 0,90. На рівні контролю була III група тварин, яка мала показник альбуміну на рівні 1,94 г\%. 3 віком цей показник у всіх групах дещо збільшився. При цьому основна маса білка представлена глобулінами в 2-х місячному віці - в порівнянні з контролем була на рівні, за винятком I групи, яка була дещо більшою на 0,14 г /\% і III групи, яка була менше контролю на 0, 16 г /\%.

у 4-х місячному віці всі показники дослідних груп були більше контролю. За даними Е. Э.В. Эйдригевича, В.В. Раевской (1978) високий рівень глобуліну збігається з більш високими добовими приростами, а їх перебільшення з альбумінами призводить до збільшення скоростиглості. Альфаі гамма глобулінові групи з віком росли, найменшою вони були в III і IV групах. Закономірностей щодо змін коефіцієнта А / Г ніхто не отримано. Бета - глобуліни, навпаки, з віком зменшувалися в дослідних групах, а в контролі були дещо меншими порівняно 32 місячним віком. Всі відмінності показників рівня білкових фракцій крові були невірогідними, як між собою, так і в порівнянні з контролем.
Незважаючи на те, що показники різниці між дослідними групами і контролем були невірогідними, майже по всім тестових дослідженнях біохімії крові, можна відзначити, що тенденція до збільшення білкових фрракцій в дослідних групах порівняно 3 контролем все ж спостерігалася. У III групі, яка показала максимальний приріст маси у віці 4 місяців рівень глобулінової фракції був більше контролю на 0,2 г 1\%, а в I і II груп на 0,41-0,59 г /\%. Це підтверджує дані про пріоритетне зростання поросят в дослідних групах у порівнянні 3 контролем.

Відомо, що будь-які подразники, в тому числі і склад і технологія годівлі, можуть викликати зміну фагоцитарних властивостей організму. Показники фрагоцитарної активності відображені в таблиці 3

Результати вивчення лізоцимної активності показали зменшення їі з віком в I і II групах в 0,88 рази і 0,93 рази і збільшення в III і IV групах в 1,04 і 1,28 рази. Найменшою в 2-х і в 4-х місячному віці лізоцимна активність була в контролі. Вірогідна різниця лізоцимної активності була в 2 місяці I i III груп при P> 0,90 у порівнянні з контролем.

Показники опсоно-фрагоцитарної реакції і лізоцимної

Таблиця 3 активності крові поросят на початок і кінець досліду

\begin{tabular}{|l|c|c|c|c|c|c|c|c|}
\hline \multirow{2}{*}{\multicolumn{1}{|c|}{ Показники }} & \multicolumn{9}{|c|}{ Періоди росту, місяці } \\
\cline { 2 - 9 } & \multicolumn{2}{|c|}{ І група } & \multicolumn{2}{c|}{ II група } & \multicolumn{2}{c|}{ III група } & \multicolumn{2}{c|}{ IV група } \\
\cline { 2 - 9 } & 2 міс. & 4 міс. & 2 міс. & 4 міс. & 2 міс. & 4 міс. & 2 міс. & 4 міс. \\
\hline Лізоцимна активність мкг/мл & $3,40 \pm 0,29$ & $3,01 \pm 0,28$ & $2,70 \pm 0,26$ & $2,51 \pm 0,16$ & $2,75 \pm 0,16$ & $2,85 \pm 0,14$ & $1,97 \pm 0,18$ & $2,53 \pm 0,10$ \\
\hline Фагоцитарна активність, \% & $35,20 \pm 1,50$ & $55,20 \pm 3,44$ & $37,60 \pm 3,25$ & $46,40 \pm 2,99$ & $36,80 \pm 5,12$ & $52,80 \pm 4,08$ & $31,20 \pm 1,96$ & $44,80 \pm 2,33$ \\
\hline Фагоцитарний індекс & $3,23 \pm 0,15$ & $3,40 \pm 0,22$ & $2,60 \pm 0,29$ & $2,93 \pm 0,31$ & $2,85 \pm 0,32$ & $2,79 \pm 0,22$ & $2,69 \pm 0,29$ & $3,22 \pm 0,38$ \\
\hline Фагоцитарне число & $1,14 \pm 0,07$ & $1,86 \pm 0,09$ & $0,96 \pm 0,10$ & $1,38 \pm 0,21$ & $1,07 \pm 0,21$ & $1,46 \pm 0,14$ & $0,84 \pm 0,10$ & $1,46 \pm 0,21$ \\
\hline Фагоцитарна ємність 10/л & $10,87 \pm 1,15$ & $6,89 \pm 0,51$ & $8,83 \pm 1,55$ & $4,09 \pm 1,01$ & $7,54 \pm 1,68$ & $5,81 \pm 1,06$ & $7,66 \pm 1,10$ & $6,75 \pm 0,98$ \\
\hline
\end{tabular}

Фагоцитарна активність з віком збільшувалася в 1,57 рази, 1,23 рази, 1,43 рази, 1,43 рази відповідно по групах в порівнянні з попереднім віковим періодом. Вірогідна була різниця в 4 місяці між I і II групами, P> 0,90 і P> 0,95 між I

Вісник Сумського національного аграрного університету 
групою і контролем. Фагоцитарний індекс і фагоцитарне число з віком збільшувалися, найбільші абсолютні показники були у поросят II групи і IV групи за першою ознакою і I групи по - другій в 4-х місячного віці. Фагоцитарна ємність з віком зменшувалася, найбільший показник якої був у поросят I групи 2-х місячного віку. Вірогідною фагоцитарна ємність була в 4 місяці між I і II групами, P> 0,95.

Висновки. Отримані дані за морфологічним і біохімі- чним складом крові поросят групи 2-4 місяці при вирощуванні з різним вмістом зернової частини комбікорму, виготовленого в умовах господарства на розробленій малогабаритній установці показали, що за показниками вмісту гемоглобіну та еритроцитів більш високопродуктивні групи тварин мали тенденцію до збільшення. Вікові зміни інших показників відповідали фрізіологічному стану і не виходили за межі фізіологічних норм.

\section{Список використаної літератури:}

1. Царенко О. М., Крятова Р. Є., Бондарчук Л. В. Ресурсозберігаючі технології виробництва свинини: теорія і практика: навчальний посібник. Суми : Університетська книеа, 2004. 269 с.

2. Демчук О. В, .Цігорлаш Д. В., Левченко М. В. Удосконалення технології виробництва кормів в експандованому вигляді та еффективність їх використання під час відгодівлі свиней. Таврійський науковий вісник № 109. Частина 2. 2004. С. 2834.

3. Зайцев В., Майстренко А., Устаткування для виготовлення кормових добавок та комбікормів. Тваринництво України. № 11-12. 2016. С.18-19

4. Рыжов С. Новые разработки по приготовлению комбикормов и кормовых смесей в хозяйствах. Комбикорма. 2000. №7. C. 15-17.

5. Васильева Е. А. Клиническая биохимия сельськохозяйственных животных / Е.А. Васильева. М: Россельхозиздат, 1982. $-254 \mathrm{c}$.

6. Кутиков Е. С., Милютина Е. И. Новый показатель состояния естественной резистентности и метод его определения. Научно-технический бюллетень УИЖ. 1992. 62. Харьков. С. 20-27.

7. Покровский А. А Биохимические методы исследований в клинике. М.-1969.-С.345-349.

8. Эйдигевич Е. В., Раевская В. В. Интерьер сельскохозяйственных животных. Изд. 2-е, переработанное и доп. - М.: Колос, 1978. - 255 с.

9. Вогнівенко Л. П., Новікова Н. В., Архангельська М. В., Папакіна Н. С., Кушнеренко В. Г., Лісна Т. М., Ференс Т. О. Зв'язок між біохімічними показниками крові свиней різної стресостійкості із їх відгодівельними якостями в умовах племзаводу ЗАТ "Фрідом фрарм бекон". Науковий вісник "Асканія-Нова". 2015. Вип. 8. С. 183-191.

10. Церенюк О. М., Акімов О. В., Бобрицька О. М., Хохлов А. М., Сусол Р. Л., Мірошникова О. С., Мартинюк І. М., Палій А. П., Палій А. П., Чалий О. І. Підвищення генетичного потенціалу продуктивності в свинарстві України : монографія. Харків: ФОП Бровін О. В., 2020. - 282 с.

11. Tsereniuk, O. M., Bobrytska, O. M., Miroshnikova, O. S., \& Danchuk, O. V. DNA-type results of Landrace sows for RYR1gene and its association with productivity. Regulatory Mechanisms in Biosystems, 2020. 11(3), 431-437. https://doi.org/10.15421/022066

\section{References:}

1. Tsarenko, O. M., Kryatova, R. E., Bondarchuk, L. V., 2004. Resursozberihayuchi tekhnolohiyi vyrobnytstva svynyny: teoriya i praktyka: navchal'nyy posibnyk. [Resource-saving technologies of pork production: theory and practice: textbook.] Sumy. Universytet·s'ka knyha, 269.

2. Demchuk, O. V, .Tsihorlash, D. V., Levchenko, M. V., 2004. Udoskonalennya tekhnolohiyi vyrobnytstva kormiv v ekspandovanomu vyhlyadi ta efektyvnist' yikh vykorystannya pid chas vidhodivli svyney [Improvement of technology of production of forages in the expanded kind and efficiency of their use during fattening of pigs]. Tavriys'kyy naukovyy visnyk, № 109(2). pp. 28-34.

3. Zaytsev, V., Maystrenko, A., 2016. Ustatkuvannya dlya vyhotovlennya kormovykh dobavok ta kombikormiv [Equipment for the manufacture of feed additives and feed]. Tvarynnytstvo Ukrayiny. no.11-12 pp.18-19.

4. Ryzhov, S., 2000. Novyye razrabotki po prigotovleniyu kombikormov i kormovykh smesey v khozyaystvakh [New developments for the preparation of feed and feed mixtures on farms]. Kombikorma. no. 7. pp. 15-17.

5. Vasil'yeva, Ye. A. 1982. Klinicheskaya biokhimiya sel'skokhozyaystvennykh zhivotnykh [Clinical biochemistry of agricultural animals]. M: Rossel'khozizdat, 254.

6. Kutikov, Ye. S., Milyutina, Ye. I. 1992. Novyy pokazatel' sostoyaniya yestestvennoy rezistentnosti i metod yego opredeleniya [A new indicator of the state of natural resistance and a method for its determination]. Nauchno-tekhnicheskiy byulleten' UIZH. 62. Khar'kov. S. 20-27.

7. Pokrovskiy, A. A., 1969. Biokhimicheskiye metody issledovaniy v klinike [Biochemical research methods in the clinic]. M. pp. 345-349.

8. Eydigevich, Ye. V., Rayevskaya, V. V., 1978. Inter'yer sel'skokhozyaystvennykh zhivotnykh. M.: Kolos, 255 p.

9. Vohnivenko, L. P., Novikova, N. V., Arkhanhel's'ka, M. V., Papakina, N. S., Kushnerenko, V. H., Lisna, T. M., Ferens, T. 0., 2015. Zv'yazok mizh biokhimichnymy pokaznykamy krovi svyney riznoyi stresostiykosti iz yikh vidhodivel'nymy yakostyamy v umovakh plemzavodu ZAT "Fridom farm bekon" [Relationship between biochemical parameters of pig blood of different stress resistance with their fattening qualities in the conditions of the breeding plant of CJSC "Freedom Farm Bacon"]. Naukovyy visnyk "Askaniya-Nova". V. 8. pp. 183-191.

10. Tserenyuk, O. M., Akimov, O. V., Bobryts'ka, O. M., Khokhlov, A. M., Susol, R. L., Miroshnykova, O. S., Martynyuk, I. M., 
Paliy, A. P., Paliy, A. P., Chalyy, O. I., 2020. Pidvyshchennya henetychnoho potentsialu produktyvnosti v svynarstvi Ukrayiny : monohrafiya. - Kharkiv: FOP Brovin O. V. 282.

11. Tsereniuk, O. M., Bobrytska, O. M., Miroshnikova, O. S., \& Danchuk, O. V., 2020. DNA-type results of Landrace sows for RYR1-gene and its association with productivity. Regulatory Mechanisms in Biosystems, 11(3), 431-437. DOl: https://doi.org/10.15421/022066

Kosov Mykola Oleksandrovych, Junior Research Fellow, Institute of Animal Husbandry NAAS

Kapitonova Olena Alevtynivna, PhD of Agricultural Sciences, Docent, Educational Institution "Vitebsk Order" Badge of Honor "state Academy of Veterinary Medicine ", Vitebsk, Belarus

\section{cal indicators of blood}

The influence of technological improvement of the methods of providing complete nutrition of pigs on biochemi-

The results of the influence of the developed balancing feed additives in the composition of small - component compound feeds made on the developed unit on the morphological and biochemical composition of the blood of piglets are highlighted. The study of the effectiveness of the use of balancing additives in the composition of small-component feed produced on the developed unit, was carried out in experimental studies to determine their productive effect on the main economic and useful characteristics of piglets on rearing. The recipe of the developed balancing additives and compound feed on the basis of a grain part from wheat and barley was carried out in production conditions on piglets of breed Welsh (2-4 months) with live weight from $20 \mathrm{~kg}$ to $40 \mathrm{~kg}$ on balanced rations on all nutrients: protein, carbohydrates, fats, minerals, vitamins, enzymes and others. The experimental groups of piglets differed in the grain part of the feed and the developed composition of BVMD for each group separately: I experimental group - barley + BVMD №1, II experimental - barley + wheat + BVMD №2, III experimental - wheat + BVMD №3, IV control - on economic diet based on barley grits. The results of the study of protein and protein fractions of blood indicate that the change in the level of total protein in the blood is observed in all groups only with age and corresponds to the physiological norm, without significant differences between experimental and control animals. At 2 months of age, the content of total protein in the serum was at the level of $6.21 \mathrm{~g} \%$ to $6.69 \mathrm{~g} \%$ with an incredible difference between the groups. Compared with him, at 4 months of age, he increased from $6.34 \mathrm{~g} \%$ to $7.25 \mathrm{~g} \%$. There was a tendency to increase the content of albumin, alpha, beta and gamma globulins with age in all groups. The results of the study of lysozyme activity showed a decrease with age in groups I and II in 0.88 times and 0.93 times and an increase in groups III and IV in 1.04 and 1.28 times. The probable difference in lysozyme activity was in 2 months of groups I and III at $P>0.90$ compared with the control. The obtained data on the morphological and biochemical composition of the blood of piglets when grown in terms of hemoglobin and erythrocytes showed that a more productive group of animals tended to increase. Age changes of other indicators corresponded to a physiological condition and did not go beyond physiological norms. Indicators of protein fractions and opsono-phagocytic reactions.

Key words: piglets, blood, opsono-phagocytic reaction, haemoglobin, leukocytes, feed additive, concentrated feed, recipe, ration.

Дата надходження до редакції: 07.11.2020 p. 